\title{
The Changing Nature of Elections in Africa: Impact on Peacebuilding
}

\author{
Franklin Oduro
}

\section{INTRODUCTION}

Elections remain central to the development of democratic and inclusive societies in Africa. Not only do elections provide means to economic growth and development since citizens can elect leaders based on their campaign promises and policies on socio-economic development, regular elections also contribute to peacebuilding by conferring authority on leaders, facilitating peaceful transfers of power, and promoting citizens' participation and inclusion in governance. Indeed, regular and credible elections have been recognized by various global, regional, subregional, and national entities and infrastructures as critical for sustainable peacebuilding. In Africa, through the African Union (AU) Charter on Democracy, Elections and Governance (ACDEG), the African Peace and Security Architecture (APSA), and the African Governance Architecture (AGA), among others, member countries have been provided guidelines

\section{F. Oduro $(\otimes)$}

Ghana Center for Democratic Development (CDD-Ghana), Accra, Ghana e-mail: f.oduro@cddgh.org

(C) The Author(s) 2021

T. McNamee and M. Muyangwa (eds.), The State of Peacebuilding in Africa, https://doi.org/10.1007/978-3-030-46636-7_10 
to ensure that the conduct of elections promotes good governance, and ensures peace and stability. ${ }^{1}$

Notwithstanding the general recognition of the centrality of elections to sustainable peacebuilding efforts, many elections have resulted in less peace and more destabilization. The continent has recorded several cases of pre- and post-election violence that have threatened stability in some countries, and generated prolonged civil wars, conflict, and violence in others such as Ethiopia (2005), Togo (2005), Kenya (2007 and 2017), Zimbabwe (2008), and Nigeria (2007 and 2011), ${ }^{2}$ to cite only a few examples. Even in countries, such as Ghana, Zambia, and Senegal where peaceful election outcomes have been recorded, the (flawed) conduct of elections has stoked fears of instability and violence, which could flare up at any time. Except for a few countries characterized by single party and/or candidate dominance, such as Rwanda, there remain uncertainties about how sustainable "peaceful outcomes of elections" are in many African countries.

This chapter provides an overview of elections and their contributions to peacebuilding in Africa. The argument is made that while elections should be viewed as a central part of peacebuilding, their impact is dependent on the regularity, inclusiveness, integrity, and credibility of election processes and outcomes. Drawing on key lessons and international best practices, this chapter highlights challenges and emerging threats to the conduct of peaceful elections in Africa. They include the increasing cost of financing elections, abuse of presidential term limits, and the increasing use of technology in the administration of elections. The final section provides four recommendations for addressing the key drivers of electionrelated violence and instability. These recommendations, informed by three decades of election experiences in Africa, are advanced in order that elections may contribute positively to peace on the continent.

\section{Elections ANd Peacebuilding}

The role of elections in peacebuilding is recognized globally. Rather than viewing them as ends in themselves, they are viewed as one (important) tool in broader efforts to promote peace and stability. Elections are part of democratic political transitions and are critical during the implementation of peace agreements. As argued by Matanock, "Post-conflict elections can greatly enhance the durability of peace agreements...specifically, [peace] agreements that enable rebel and government parties to 
participate in elections." 3 Accordingly, international assistance for peacebuilding programs, including deployments by the United Nations (UN) and its affiliated agencies, invariably have an election component. This is particularly true of post-conflict and/or transitional settings, which are common in Africa. ${ }^{4}$

Post-conflict or transitional elections create the opportunity for all stakeholders to contribute to building legal and constitutional frameworks, as well as democratic institutions that advance a sustainable peacebuilding agenda. In addition, because election periods provide a path-for many citizens, the only path-to political participation, they create the feeling of belonging, thereby fostering inclusion and unity which, in turn, promotes peace. In other words, the electoral imperative, the opportunity for citizens to periodically participate in leadership change through a credible and competitive process, offers the promise of peace and stability in societies. ${ }^{5}$ Fundamentally, the link between elections and peacebuilding is premised on the belief that regular and credible elections offer the most promising instrument for addressing and managing societal tensions and conflict without the use of violence. ${ }^{6}$

\section{Three Decades of Elections in Africa: What Do We Know About Their Impact on Peacebuilding?}

Whereas the nexus between elections and peacebuilding is widely understood in its positive manifestations-e.g., allowing citizens to choose their political leaders freely and, thus, allocate power peacefully-there is also clear evidence to suggest that elections have often triggered violence and undermined peacebuilding on the continent. Mostly, this is due to the way elections are conducted. A poorly conducted election can ignite the underlying tensions in societies, already amplified by the very highstakes-e.g., "winner-takes-all"—associated with electoral competition in Africa. Studies on electoral violence in Sub-Saharan Africa highlight a number of factors and threats to electoral peace. ${ }^{7}$ For example, Straus and Taylor, examining data from 1990 to 2007, suggest a typology of election violence that ranges from low intensity to violent harassment and large-scale violence, which results in death and instability. ${ }^{8}$

Election-related violence on the African continent has been variously influenced by: 
i. Intense competition- “winner-takes-all” mentality—among political elites for state power and resources ${ }^{9}$;

ii. weak election management bodies (EMBs);

iii. flawed electoral registers; and

iv. a lack of transparency and/or inadequate pre-election preparations.

These and other factors ${ }^{10}$ contribute greatly toward a deficit in trust in elections among citizens and electoral opponents.

The story is not all negative, however. Regular elections have increasingly become the norm in Africa. Acceptance by citizens ${ }^{11}$ and political elites that the ballot box is the only legitimate means for electing leaders is now widespread. This is a far cry from the past when leaders ruled through the barrel of a gun in many parts of Africa. Not anymore. The compliance of ACDEG protocols regarding regularity of elections in member countries is growing. A recent study assessing compliance of six AU-member countries (Ghana, Ethiopia, Rwanda, South Africa, Zambia, and Nigeria) on regular elections confirmed as much, although capacity to conduct elections varied across the studied countries. ${ }^{12}$ While regularity of elections is improving, their quality remains a serious concern. Even with this concern, the fact that political elites and citizens prefer elections, rather than other methods, for choosing leaders and allocating power is beneficial to peacebuilding efforts in Africa.

Gradually, election management bodies are getting better and becoming more professionalized. This has helped to drive even more demand for transparency in election preparations and management. The application of technology is also helping EMBs to address other concerns and build societal trust in electoral processes. EMBs in Africa have been the test-bed for biometric technology in registering potential voters. Where it has been introduced effectively, it has improved the integrity of voter registers and enhanced transparency in the collation and declaration of results. All of this has helped to make elections in some countries more credible and thus minimize their potential for triggering violence and instability.

As a result of the improvement in election administration and increasing professionalism of EMBs, the continent is also experiencing increasing (even if sometimes difficult) acceptance of election results by losing candidates, and thereby effecting peaceful election outcomes. ${ }^{13}$ The accompanying leadership transitions recorded in Benin, Senegal, Nigeria, Ghana, Sierra Leone, and Liberia are significant success stories 
that are contributing to reducing tensions surrounding the conduct of elections.

Finally, the contributions of elections to peacebuilding processes in Africa cannot be discussed without acknowledging the role of election monitors and observers, both domestic and international. Despite some limitations, the short- and long-term observation activities of election observers, are contributing to and supporting peaceful election outcomes. The AU's electoral assistance division within the department of political affairs has played a critical role and continues to provide critical support and observation missions (both long-term and short-term) to African countries in compliance with ACDEG. The AU's presence and role in elections in Nigeria (2015 and 2019), Ghana (2016), Kenya (2017), Liberia (2017), and Sierra Leone (2018) are clear cases for reference, where their role in promoting peace before, during, and after elections was critical. As Lappin argues, while admitting limitations, “...international election observation missions (IEOMs) remain essential elements to peacebuilding..." 14 Those limitations were most starkly evident during the 2019 elections in Malawi, where the African Union Election Observationer Mission reported that "...the elections took place in a peaceful, transparent and orderly manner, and thus met national, regional, continental and international standards for democratic elections..." 15 For their part, the European Union's Election Observation Mission, which covered 27 of the 28 voting districts of Malawi in its preliminary report, concluded that despite an unlevel playing field, the election was "Wellmanaged, inclusive, transparent and competitive."16 However, Malawi's own Constitutional Court concluded in 2020 that this assessment was flawed, thus confirming allegations of widespread irregularities. It ordered new elections, which resulted in the defeat of the winner of the annulled 2019 vote. $^{17}$

Both positive and negative voting experiences have served to heighten Africa's focus on developing best practices and institutional reforms to ensure elections that better serve the interests of peace. Among many lessons learned, two stand out: first, the negative consequences of the persistent "winner-takes-all" mentality; and second, that the timing and sequencing of elections are crucial, particularly in transitional periods. 


\section{Winner-Takes-All Politics}

The "winner-takes-all" nature of African politics can be especially insidious come election time, owing to the high stakes involved. The desire of African political elites to capture state power, and by extension state resources for themselves and their cronies, has fueled the quest to secure election victory at any cost. As Atta-Asamoah notes, "Such [winner-takesall] politics, if left unchecked in the context of the complex cocktail of development and security challenges in Africa, could derail the sustainability of democratic gains, development strides, and the maintenance of peace and security in many fragile states." 18

To curtail this trend, reforms should be made to key governance institutions-such as the legislature as a countervailing force to the executive branch of government; constitutions to foster broad-based inclusive politics - and to electoral systems (e.g., move away from "first past the post" and toward "proportional representation" and "mixed plurality"). ${ }^{19}$ With particular reference to electoral systems, and as argued elsewhere with respect to the Southern African Development Cooperation (SADC) region, Khabele Matlosa, for example, recommends that "SADC states must make deliberate efforts to address election-related conflicts and war by, among other things, reforming their electoral systems." 20 Observations seem to suggest that the "first past the post" systems tends to amplify the "winner-takes-all" approach. This, in turn, raises the potential for election-related violence.

\section{Sequencing and Timing}

A badly timed election can, sometimes, be worse than having no election at all. Promoters of democracy and good governance, whether foreign or local, tend to push for elections at the first opportunity during transitional settings. This is not always good for building sustainable peace. ${ }^{21}$ Where peace is still fragile and trust is lacking, EMBs are usually poorly resourced; basic legal and institutional reforms have not been implemented; new and opposition political parties have not been given sufficient time to prepare; and elections are often hurriedly organized. All of these factors can impede democratic progress.

As Fath-Lihic and Brancati argue, the ability of national and international policy actors to understand and assess the complex political, legal, technical, operational, participatory, and security-related challenges 
in determining the ideal timing for the conduct of transitional elections is critical for peacebuilding processes. A “one-size-fits-all” election solution, they add, does not exist. Every transition is different. Much depends on historical context, the nature of the conflict, and what the elections are designed to achieve, which is not always as straightforward as it seems. ${ }^{22}$

"Elections are often the final stage of a peace process, if not the ultimate objective," observe McNamee et al. "The hope is that elections can have a stabilizing effect on a fractured society. Done well and timeously, they can. But conducted too early, before security problems have been converted into political problems, they can have the opposite effect: exacerbate divisions and foment violence." 23 Fostering local ownership and inclusivity, building trust and promoting broad-based popular support for electoral processes are vital. The benefits to peace of encouraging a national tone of mutual respect and tolerance during the electoral phases (pre, during, and post) are also not to be underestimated.

\section{Challenges and Emerging Threats to Election Peace in Africa}

In addition to the failings highlighted above, elections during the past decade have revealed new and emerging problems which can serve to undermine peace and stability. These emerging issues, including failures in the (increasing) application of technology during elections, mounting legal challenges to election results by contenders, incumbents ignoring term limits, and the rising cost of elections, merit closer scrutiny.

\section{Technology and Elections}

In some cases, the use of biometric technology by EMBs in the registration and authentication of voters has helped to counter voter fraud and enhance the credibility of electoral registers. Recently, EMBs have also been scaling up efforts-notably in Ghana, Kenya, and Nigeriato use information technology to increase transparency in election results transmission. ${ }^{24}$ In other instances, however, the introduction of new technologies has led to myriad problems, with negative consequences for stability and peace. Questions about the procurement and management of the equipment, equipment breakdowns, unreliable devices, and the suspect integrity and poor handling of these devices by election officials 
have been common. ${ }^{25}$ Failures in the collation and transmission of election results in Kenya resulted in a period of grave uncertainty, as the "defeated" opposition successfully disputed the results of the election, then withdrew from the subsequent re-scheduled vote. Many feared that the political turmoil sparked by the 2017 election saga would trigger a repeat of the $2007 / 2008$ election violence. Fortunately, this did not happen.

All the evidence suggests that, despite these and other problems such as weak transparency and inclusion in procurement practices, Africa's EMBs are pushing for more information technology in election management. But that push, in itself, can be detrimental to situations where elections become a tool for promoting peacebuilding. Recent electoral processes and outcomes have exposed weaknesses in the methods and conduct of election observers. Their ability, for example, in the era of tech-driven elections to detect potential manipulation at results collation centers seems limited. As Judd Devermont points out, "Most observers do not have the technological expertise to counter... [and] circumvent government internet controls, safeguard election results from hacking, or detect digital tampering." 26 Hacking and other digital attacks can effectively undermine many of the key ingredients of election integrity: voter registration, vote casting, and vote tabulation. As many analysts have also observed, the timing and context in which election-related information, communication, and technology are introduced often do not allow for adequate time for familiarization by opposition parties. ${ }^{27}$ The risks of politicization become high at a very early stage, meaning that many election results have already been effectively rejected by the opposition well before the election itself is actually held.

\section{Litigating Election Results}

Recent elections in Nigeria (2011 and 2019), Ghana (2012 and 2016), Kenya (2017), Liberia (2017), Sierra Leone (2018) and Malawi (2019) 28 gave rise to new dynamics in election dispute management and potential threats to stability. The resort to judicial processes to contest election results in these cases is, obviously, a progressive step forward from the extra-judicial means used in the past to contest and change electoral outcomes. That said, this trend presents its own challenges to peacebuilding. 
When the judiciary is put at the center of deciding election outcomes, it also ends up pronouncing on them. Though the difference in language is subtle, the implications can be significant. Judicial pronouncements on election outcomes will be based on interpretations of the law, technicalities, procedures, and legal principles which may contradict vote tallies. Citizens who feel that their votes have been overturned by seemingly abstract judicial rulings may be more susceptible to joining violent forms of resistance and mass mobilization. They may even be given succor by alternative swearing-in ceremonies (as recently witnessed in Kenya) where the opposition candidate claims "victor status" despite official results not going his or her way. ${ }^{29}$ Civic education in Africa has not sensitized people to the idea that one's chosen candidate can "win" the election at the ballot box but lose it in court.

The length of judicial litigations on election outcome disputes could also serve as potential triggers for election violence. The decision by the Kenyan Supreme Court after the 2017 election is a case in point. The relative speed (within a month) with which the court concluded on the petition brought before it by the opposition parties raised concerns that the court did not spend adequate time examining the case and competing arguments before deciding to annul the election results. In Ghana, the opposite occurred: the post-2012 election petition to the Supreme Court on the results of the presidential election took too long. The eight-month delay created a wellspring of anxiety across society, which could have boiled-over in a country where the declared winner was in office but not yet confirmed as legitimate.

On the face of it, there is nothing wrong with the judiciary playing a greater role in ensuring elections are sound. The Malawi Constitutional Court's decision to order a re-run of the 2019 election has generally been viewed as a boost for Malawi's journey toward democracy. But as more disgruntled politicians and parties try to exploit potential loopholes in electoral laws in African countries, weak election administration infrastructures are exposed. Judiciaries cannot be expected to fill this gap-balancing interpretations of rules and technicalities and legal principles against the will of the people, however that might be determined. A recent study illustrated some of the dangers: in the case of Nigeria, it argues that its judiciary has been complicit in perpetrating electoral fraud in Nigerian elections. ${ }^{30}$ The authors conclude that, while the Nigerian political class sees the judiciary as another platform for resolving election disputes, the manipulation of the judiciary and its associated process to 
perpetrate electoral fraud has resulted in a high level of public mistrust of the judiciary. ${ }^{31}$ Resolving this electoral conundrum will be critical to the future of peacebuilding in Africa.

\section{Abusing Presidential Term Limits}

Another emerging threat to election peace relates to attempts by ruling elites to extend their stay in office through removal of constitutional term limits, mostly against the wishes of their populations. ${ }^{32}$ In the postCold War era, approximately 30 African leaders have attempted to change constitutional impositions to extend their rule-in perpetuity, in some cases-and almost half of these attempts have succeeded. ${ }^{33}$ The idea of "third termism" can sometimes be described as lawful, due to the constitutional procedures adopted to legitimize the changes in the law, but the popular opposition to such moves stores up considerable potential for violence and instability. Moreover, attempts by African political leaders to extend their stay in power typically precludes opportunities for multi-party electoral engagements.

The absurd corollary of the "president for life" trend-that opposition parties aren't allowed to compete for office-foments myriad extra-legal/judicial means of seeking power. As Taylor et al. argue, election-related violence is more likely in situations where incumbents have unfettered right to contest elections; conversely, where incumbents don't run, violence becomes less likely. ${ }^{34}$

\section{Increasing Cost of Financing Elections and Elective Politics}

The increasing cost of financing African elections is another potential threat to peacebuilding. ${ }^{35}$ Due to limited resources, African countries have turned more and more to donor partners, especially Western partners, to fund their elections. This trend raises stark questions about resilience and sustainability: what happens if traditional funding streams suddenly dry up? Will governments be more inclined to suspend or delay elections, or indeed not have them at all? And what will be the consequent impacts on peace and stability? Through logistics and (putative) funding-related delays in holding scheduled elections over more than two years, from 2016-2018, the government of the Democratic Republic of the Congo (DRC) ${ }^{36}$ was perhaps lucky to have escaped with only minor eruptions of violence by discontented Congolese. 
It is not just the cost of the elections themselves that is problematic; campaign financing can also seed security problems. The increasing cost of electoral campaigns makes it difficult for opposition parties to compete on a level playing field. Ruling parties and candidates often raid state coffers to fund their campaigns; opposition parties might not be able to secure private funding, owing to fears of the private sector, especially companies, that opportunities for business with the state will be closed if they are found to be funding the opposition. Significantly, electoral politics in much of Africa has become the sole preserve of the rich. A study in Ghana revealed that around US $\$ 86,000$ was spent on average by members of parliament in their election campaigns. ${ }^{37}$ This is completely out of reach for the vast majority of Africans, adding to concerns of inclusivity. If money alienates ordinary Africans from electoral politics, this is bad for peacebuilding in the long-term.

Africa needs to take a hard look at its electoral systems and decide whether to encourage peace or promote division. The "winner-takes-all" politics common across Africa are a significant trigger of election-related conflict. ${ }^{38}$ Any system that encourages political exclusion, Gyampoh argues, "can, potentially, jeopardize the fragile election peace." ${ }^{39}$ Alternatives such as proportional representation have their own shortcomings, but to the extent that proportional representation lessens the marginalization of losers and spreads the benefits of victory more widely, it can reduce the likelihood of elections undermining peace and peacebuilding.

\section{Key Recommendations}

Strengthening the integrity and quality of electoral processes in Africa will contribute positively to peacebuilding. This requires a multifaceted response on the part of local, national, and international stakeholders, including organizations specializing in elections and democratic assistance and consolidation. As part of this holistic response, four specific policy recommendations are offered below.

\section{Re-examine electoral laws in African Union-member countries.} There is a need to re-examine electoral laws in order to ensure that these laws are in compliance with provisions in the African Union Charter on Democracy, Elections and Governance (ACDEG). The recurring challenge in deepening democratic governance in Africa 
has, generally, been the failure of African Union member countries to domesticate various protocols and charters to which they are signatories. After three decades of operating transitional electoral laws, there has yet to be an adequate sifting of the policies and protocols which have worked from those that have not. The reforms should address electoral processes as well as rules and legislation that promote a level playing field, reducing the unfair advantage held by incumbents. Such a review must take into account gaps and non-compliance that result in electoral disputes and litigations, as well as a lack of transparency and inclusiveness. Given the regularity of elections and their changing dynamics, Africa needs new or updated mechanisms to address election-related threats to peace and stability. Pro-democracy organizations working to strengthen election management bodies should be at the forefront in engaging with these growing threats.

2. Confront the challenges related to the growing use of technology in the administration of elections. There is a critical need to stimulate global and continental discussions on emerging challenges to election observers' work in an era of technologically driven election administration. Independent and non-partisan citizen election observation groups, who are already incorporating information technology in their observation as well as international election observer missions, must begin to find ways of including verification protocols in electronic transmittal and collation of election results in their observation programs. With increasing sophistication in election administration, election observer groups must also align their protocols to the emerging threats to election peace. "...like modern-day police chasing cyber-thieves instead of masked bank robbers, international observers must adapt to new technologies." 40 Accordingly, it may be prudent to review the Declaration of Global Principles for Non-Partisan Election Observation and Monitoring by Citizen Organizations, and Code of Conduct for Non-Partisan Citizen Election Observers and Monitors to take into account protocols for addressing gaps in the more obscure aspects of election technology processes, i.e., the back-end. By addressing this gap, the reports of election observer groups will be more reliable and better received by host countries. Creating spaces for observer groups to engage election management bodies in this area of election administration is critical for enhanced transparency, trust-building, and inclusiveness. 
3. Assure sustainable financing of elections. Stakeholders, especially international democracy promoters, must engage on the issues of financing. In order to forestall opportunities for leaders to use a lack of resources as an excuse to suspend elections, it is imperative to develop ways for instituting sustainable financing of elections. Such mechanisms could include the establishment of national election funds designed in a manner that the ruling government does not have a say in its management. The policy response should also include instituting predictable national and international sources of funding, and accountable mechanisms to ensure transparent and judicious use of resources for election administration. In this instance, groups such as the International Foundation for Electoral Systems (IFES), regional economic communities (RECs) in Africa, the African Union Department of Political Affairs, and other global democracy promoters must lead in advocating for such a fund. Exploring ways to address sustainable financing of elections must be accompanied by campaign finance reform to create a more level playing field, and to assure inclusiveness and integrity of elections.

4. Counter the trend to eliminate presidential term limits. A continental and sub-regional response is required to address the trend toward serving beyond constitutionally mandated presidential term limits. This will require sustained, long-term advocacy from all corners, but perhaps especially the African Union and the regional economic communities. For instance, the Economic Community of West Africa (ECOWAS) was close to instituting such a protocol for its members but failed when two members, Togo and The Gambia, objected to the decision. ${ }^{41}$ With the exit of president Yahya Jammeh in The Gambia and the reforms that have occurred in Togo, there is a window of opportunity for civil society actors to begin a campaign for ECOWAS to revisit the subject.

\section{Notes}

1. The African Charter for Democracy, Elections and Governance (ACDEG), adopted in 2007, articulates the universal values of democracy and respect for human rights that are founded on supremacy of the constitution and the holding of democratic and credible elections.

2. Dorina A. Bekoe (ed.), Voting in Fear: Electoral Violence in Sub-Sabaran Africa (Washington, DC: United States Institute of Peace Press, 2012). 
3. Aila M. Matanock, "How Elections Can Lead to Peace: Making Negotiated Settlements Last," Foreign Affairs, April 25, 2018.

4. Annette M. Fath-Lihic and Dawn Brancati, Elections and Peacebuilding: Why Timing and Sequencing of Transitional Elections Matter (Geneva: Electoral Integrity Initiative Policy Brief no. 4, Kofi Annan Foundation, 2017).

5. Adelaja Odukoya, "Democracy, Elections, Election Monitoring and PeaceBuilding in West Africa," African Journal of International Affairs 10, no. 1-2 (2007): 147-160.

6. Richard Lappin, "Why Observe Elections? Reassessing the Importance of Credible Elections to Post-conflict Peacebuilding," Peace Research: Canadian Journal of Peace and Conflict Studies 41, no. 2 (2009): 86-117.

7. Dorina Bekoe, “Africa's Electoral Landscape: Concerning Signals, Reassuring Trends," African Center for Strategic Studies, May 16, 2016, https://africacenter.org/spotlight/sub-saharan-africas-electoral-lan dscape-concerning-signals-reassuring-trends/.

8. Scott Straus and Charlie Taylor, "Democratization and Electoral Violence in Sub-Saharan Africa, 1990-2008," in Voting in Fear: Electoral Violence in Sub-Saharan Africa (Washington, DC: United States Institute of Peace Press, 2012).

9. For detailed discussions on the implications of "winner-takes-all" phenomenon on inclusive governance and peacebuilding, see Ransford Gyampoh, "Winner-Takes-All Politics in Ghana: The Case for Effective Council of State," Journal of Politics and Governance 4, no. 1-4 (December 2015): 17-24; and Andrews Atta-Asamoah, "Winner-TakesAll Politics and Africa's Future," Institute for Security Studies, https://iss africa.org/amp/iss-today/winner-takes-all-politics-and-africas-future.

10. Such as unfair electoral rules and unfair playing field, technical incompetence of members of EMBs, and appearance of incumbent control and influence of EMB.

11. Interviews conducted by the Afrobarometer Research Network between 2016 and 2018 reported that 75 percent of Africans (across 34 countries) preferred to use regular, open, and honest elections to choose country leaders. See "Africans Want High-Quality Elections-Especially If They Bring Change, Afrobarometer Surveys Show," Afrobarometer, June 26, 2019, https://afrobarometer.org/sites/default/files/pressrelease//ab_ r7_pr_africans_want_high_quality_elections_especially_if_they_bring_cha nge.pdf.

12. Anne McLennan, "Democratic Governance," in Civil Society Perspectives on African Union Member States Commitments to Democratic Governance (Johannesburg: Wits School of Governance, University of Witwatersrand, 2017). 
13. Judd Devermont notes that since 2015, 13 opposition parties have won elections and defeated incumbent parties, which is contrary to experiences in the past two decades. See Judd Devermont, The Game Has Changed: Rethinking the U.S. Role in Supporting Elections in Sub-Sabaran Africa (Washington, DC: Center for Strategic and International Studies, 2019).

14. Lappin, "Why Observe Elections?" 87.

15. See https://au.int/sites/default/files/documents/38117-doc-report_of_ the_african_union_election_observation_mission_to_the_21_may_2019_t ripartite_elections_in_the_republic_of_malawi.pdf, 9.

16. See https://eeas.europa.eu/election-observation-missions/eom-malawi2019_en/63055/EU\%20EOM\%20Malawi\%20presents\%20its\%20Prelimi nary\%20Statement.

17. See https://www.theguardian.com/world/2020/jun/27/oppositionwins-rerun-of-malawis-presidential-election-in-historic-first.

18. Atta-Asamoah, "Winner-Takes-All Politics and Africa's Future."

19. Gyampoh, "Winner-Takes-All Politics in Ghana," 17-24; Ransford Edward Van Gyampoh, "Dealing with Ghana's Winner-Takes-All Politics: The Case of an Independent Parliament," African Review 42, no. 2 (2015): 63-75; Ransford Edward Van Gyampoh, "Dealing with Ghana's Winner-Takes-All Politics: A Case for Proportional Representation?" The Journal of Social Sciences Research 1, no. 4 (2015): 41-46; Nic Cheeseman, Karuti Kanyinga, Gabrielle Lynch, Mutuma Ruteere, and Justin Willis, "Kenya's 2017 Elections: Winner-Takes-All Politics as Usual?" Journal of Eastern African Studies 13, no. 2 (2019): 215-234; Khabele Matlosa, "Review of Electoral Systems and Democratisation in Southern Africa" (Paper, International Roundtable on the South African Electoral System, Cape Town, South Africa, September 9-10, 2002); and David Thomas, "End 'Winner Takes All' Politics-Osinbajo," New African, April 21, 2015, https://newafricanmagazine.com/10741/.

20. Matlosa, "Review of Electoral Systems and Democratisation in Southern Africa."

21. Fath-Lihic and Brancati, Elections and Peacebuilding; Sead Alihodzic, Nicholas Matatu, Oliver Joseph, and Katrin Lewis, Timing and Sequencing of Transitional Elections (Policy Paper No. 18, International IDEA, 2019); and Terence McNamee, Nchimunya Hamukoma, and ChipokoaMayamba Mwanawasa, Elections in Africa: Preparing a Democratic Playbook (Johannesburg: The Brenthurst Foundation, 2017).

22. Fath-Lihic and Brancati, Elections and Peacebuilding, 9.

23. McNamee, Hamukoma, and Mwanawasa, Elections in Africa, 17.

24. "2019: Election Results Will Be Transmitted Electronically from Polling Units-INEC," Vanguard, December 5, 2017, https://www.vangua rdngr.com/2017/12/2019-election-results-will-transmitted-electroni cally-polling-units-inec/; Lois Ugbede, “2019: INEC Seeks NCC’s Help 
to Electronically Transmit, Collate Results," Premium Times, January 31, 2018, https://www.premiumtimesng.com/news/more-news/2571512019-inec-seeks-nccs-help-electronically-transmit-collate-results.html.

25. Rhoda Osei-Afful, "Solutions or Problems? The Increasing Role of Technology in African Elections," African Up Close (blog), Wilson Center, December 11, 2017, https://africaupclose.wilsoncenter.org/solutions-orproblems-the-increasing-role-of-technology-in-african-elections/.

26. Devermont, The Game has Changed, 6.

27. McNamee, Hamukoma, and Mwanawasa, Elections in Africa, 9-12.

28. Recent elections conducted in these countries witnessed judicial litigations in various forms in the pre-election and post-election phases, including litigation on results collation, transmission and declaration.

29. Devermont, The Game Has Changed, 5.

30. Hakeem Onapajo and Ufo Okeke Uzoduke, "Rigging Through the Courts: The Judiciary and Electoral Fraud in Nigeria," Journal of African Elections 13, no. 2 (2014): 137-168.

31. Onapajo and Uzoduke, "Rigging through the Courts," 161.

32. Boniface Dulani, "African Publics Strongly Support Term Limits, Resist Leaders' Efforts to Extend Their Tenure," Afrobarometer, May 25, 2015, http://afrobarometer.org/sites/default/files/publications/Dispat ches/ab_r6_dispatchno30.pdf.

33. McNamee, Hamukoma, and Mwanawasa, Elections in Africa; Ibraheem Bukunle Sanusi and Rizzan Nassuna, Emerging Trends in Africa's Election Processes (Cape Town: Policy Brief No. 158, South African Institute of International Affairs, 2017).

34. Charles Fernandes Taylor, John C. W. Pevehouse, and Scott Straus, "Perils of Pluralism: Electoral Violence and Incumbency in Sub-Saharan Africa," Journal of Peace Research 54, no. 3 (2017): 397-411.

35. In Ghana, it is reported that the recent 2016 elections cost 35 times more than the cost of 2004 elections. See "This Is the Cost of Elections in Ghana," Pulse, November 17, 2016, http://www.pulse.com.gh/ news/politics/election-2016-this-is-the-cost-of-elections-in-ghana-id5 772116.html. In Kenya, the 2017 elections were projected to be the most expensive in Africa. See "Kenya Campaign Projects Now in Doubt as Polls Cost Shoots to $\$ 500 \mathrm{~m}$," The East African, July 16, 2017, http://www.theeastafrican.co.ke/news/Kenya-most-expensive-electionsin-the-world-/2558-4016484-5dw5jhz/index.html; Abdi Latif Dahir, "Kenya Is Set to Hold One of the Most Expensive Elections in Africa," Quartz Africa, July 18, 2017, https://qz.com/1030958/kenyas-electi ons-will-cost-1-billion-in-government-and-campaign-spend/; McNamee, Hamukoma, and Mwanawasa, Elections in Africa, 13-14.

36. Jason Burke, "DRC Minister Says Country 'Can't Afford' to Hold Election This Year," The Guardian, February 16, 2017, https://www. 
theguardian.com/world/2017/feb/16/delayed-drc-elections-could-beput-back-further-by-cash-shortage; Vince Chadwick, "Donors Fall Short of Targets on Funding Pledges for DRC, But See Progress," Devex, April 16, 2018, https://www.devex.com/news/donors-fall-short-of-targetson-funding-pledges-for-drc-but-see-progress-92543; David Pilling, "Congolese Opposition Calls for Foreign Cash to Fund Election," Financial Times, March 27, 2017, https://www.ft.com/content/fd05134c-04e711 e7-ace0-1ce02ef0def9.

37. Even this estimated figure has been described as very conservative and too low by Ghanaian Members of Parliament. "MPs Spend US \$86,000 to Get Elected-Study," MyJoyOnline, February 4, 2018, https://www. myjoyonline.com/politics/2018/February-4th/mps-spend-us86000-toget-elected-study.php; "Each MP Spends GHC390,000 on Election Campaign-Report," Citi 97.3 FM, February 5, 2018, http://citifm online.com $/ 2018 / 02 / 05 / \mathrm{mp}$-spends-ghc390000-election-campaign-rep ort/; “\#GhanaElections 2016-Facts and Figures," Ghana Election 2016, December 6, 2016, http://www.africanelections.org/ghana/news_detail. php?nws $=7480 \& \mathrm{xt}=$.

38. Gyampoh, “Dealing with Ghana's Winner-Takes-All Politics: A Case for Proportional Representation?"

39. Ibid., 42.

40. Nic Cheeseman, Todd Moss, and Jeffrey Smith, "IT'S time for International Election Monitors to Start Doing Their Job," DemocracyPost, The Washington Post, November 15, 2017, https://www.washingto npost.com/news/democracy-post/wp/2017/11/15/its-time-for-intern ational-election-monitors-to-start-doing-their-job/.

41. "W. African Leaders Drop Term Limit Idea After Gambia, Togo Oppose," Reuters, May 19, 2015, https://www.reuters.com/article/westafricademocracy-limits /w-african-leaders-drop-term-limit-idea-after-gambiatogo-oppose-idUSL5N0YA52820150519; "Gambia and Togo Opposte Presidential Term Limits," CGTN Africa, May 20, 2015, https://africa. cgtn.com $/ 2015 / 05 / 20 /$ gambia-and-togo-oppose-presidential-term-lim its/. 
Open Access This chapter is licensed under the terms of the Creative Commons Attribution 4.0 International License (http://creativecommons.org/licenses/ by $/ 4.0 /$ ), which permits use, sharing, adaptation, distribution and reproduction in any medium or format, as long as you give appropriate credit to the original author(s) and the source, provide a link to the Creative Commons license and indicate if changes were made.

The images or other third party material in this chapter are included in the chapter's Creative Commons license, unless indicated otherwise in a credit line to the material. If material is not included in the chapter's Creative Commons license and your intended use is not permitted by statutory regulation or exceeds the permitted use, you will need to obtain permission directly from the copyright holder.

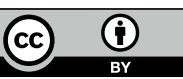

